\title{
Demand-oriented innovation policy: Mapping the field and proposing a research agenda for developing countries
}

\begin{abstract}
This article conducts a scoping review of demand side innovation policies and its associated instruments in relevant English language academic literature. Demand-side innovation policies aim to improve contextual conditions to encourage innovation adoption to address government-defined societal challenges. From the demand approach, innovation policy is expected to involve a directionality, which originates from collective priorities around relevant problems. Based on a scooping review of the innovation policy literature from the demand perspective, this research has characterized trends in the discussion about innovation policies that target such challenges, a perspective that complements the traditional supply side policy instruments. Findings indicate that literature on demand-side policies has mainly addressed energy and sustainability issues in European countries and China. Additionally, although demand-side policies have been advocated for a relatively long time, the literature recognizes that a policy mix involving also the supply-side can be more effective in encouraging innovation. In Latin America, demand-side policies have been poorly understood, leading to a defective implementation of policies and instruments. The stage of research on demand-side policies is still evolving and this article advances research propositions on innovation policy, with a deep focus on how they can be implemented in innovation-lagging developing countries.
\end{abstract}

Keywords: Innovation policy; Innovation; Supply-side, Developing countries; Problem-solving policy.

Corresponding author: e-mail: pavelreyesmercado@ hotmail.com

Received 25 Oct 2019 - Accepted 24 Dec 2019

This is an Open Access article distributed under the terms of the Creative Commons Attribution-Non-Commercial-No Derivatives License (http://creativecommons.org/licenses/by-nc-nd/4.0/), which permits non-comercial re-use and distribution, provided the original work is properly cited, and is not altered or transformed in any way. 


\section{Introduction}

Government institutions in charge of the development of science, technology and innovation have implemented policies and incentives to support academic organizations, companies and start-ups in their technology development and innovation. Typically, these policies originate from an approach that aims to encourage the advancement of innovation through capacity building (Cimoli 2013, 144; Lundvall et al. 2011, 144), which may have resulted, in some cases, in the development of new products and services, usually technology-based, that are eventually commercialized in the market. However, little progress has been made in the study of those policies that lead these organizations to scalable results from a systemic perspective, beyond the behaviour of the individual or the conditions that foster innovation (Acs and Correa 2015, 5). Hence, it is essential to place greater emphasis on the role of demand as a systemic element that encourages scientific and technological innovation, whose potential economies of scale have been identified as the key element associated with high-impact entrepreneurship (Acs 2008, 63; Acs 2010, 13).

There is a variety of factors that encourage or discourage innovation (Anisimov 2015), and innovation policy aims to identify the right combination of such variables that help the innovation process to develop, particularly those innovations that are relevant to society and governments (Edler and Fagerberg 2017, 4). Innovation policy instruments are the public measures used by the State to achieve a desired effect (Zhi et al. 2014, 309), whose application is context-dependent (Edler and Fagerberg 2017, 4). Innovation policy makes sense in the case of market failure, innovation system failure, or to achieve a specific societal mission (Bugge et al. 2018, 470). According to Bugge et al. (2018, 478), innovation policy making is today widely inclusive towards solving societal challenges. 
In general, innovation policy has been classified in two groups: supply-side (SS) and demandside (DS). SS policies seek to build capabilities in economic agents to innovate and commercialize (Edler et al. 2012, 35). This objective ought to be achieved through: 1) investment subsidies; 2) grants and fiscal incentives for $R \& D$; 3 ) direct support to private innovation and start-up firms (e.g. training, consulting services, clusters, innovation networks and co-working spaces); 4) regulation to foster more innovation (e.g. intellectual property rights); and 5) financial support for new born or small and medium-side enterprises (Langer 2001, 399; Edler et al. 2012, 35; Jang et al. 2015, 12603; Edler and Fagerberg 2017, 11; Hanley and Douglass 2014, 222).

Conversely, DS policies improve conditions for the uptake of innovations (Edler et al. 2012, 34). Their main goal is to encourage the use of the innovation (Zhi et al. 2014, 318) by developing and creating new markets (Langer 2001, 395). This objective is achieved through 1) consumer subsidies; 2) the influence of the State in its role as a purchaser (public procurement); 3) training and creating awareness mechanisms to build up and broaden absorptive capacity for innovation; 4) policies to mitigate deficiencies in the flow of information between buyers and suppliers; 5) feed-in-tariffs, net metering, green tags, renewable energy portfolios; 6) financial support for users; and 7) Government mandates and regulatory framework to structure the market in favour of innovations (Edler et al. 2012, 38). In general, network effects, aggregate demand, technological developments, changes in market structure, regulations, large buyers and pre-commercial public policies are some of the mechanisms identified as DS policies (Edquist 2011, 1734; Henrekson and Stenkula 2010, 603; Priem et al. 2002, 349). 
This study examines recent scholarly literature on innovation policy and classifies the empirical experience of DS and SS-oriented instruments by geography, sector and tactical combinations of such instruments, delivering a broad synopsis of innovation policy research. To achieve this objective, this paper conducts a research team-based scooping review of literature on innovation policy instruments, capturing trends and research perspectives on innovation policies from both the SS and DS perspectives.

The article is structured as follows: Section 2 details the steps taken to carry out the scooping review of literature. In Section 3, a thematic analysis of existing literature is presented, which focuses on the identification of regional, sectoral and tactical approaches present in the scholarly literature. A discussion of findings along with research proposals is developed in Section 4. The article closes with implications for policy makers and researchers in Section 5.

\section{Method}

To include the broad body of theoretical and empirical studies and to map the main concepts underlying innovation policy, this article opted to conduct a scoping review of literature. A scoping study was deemed suitable since it investigates the extent, depth, and different types of existing studies, summarize them, and identify research gaps (Arksey and O'Malley 2005, 21). Instead of handling the narrower research questions and quantitative nature of systematic reviews of literature, scoping reviews can handle a broad range of study designs in disciplines with emerging evidence that makes difficult to conduct a systematic review (Levac et al. 2010, 3). Since scoping reviews were originally devised to serve the purposes of medical and health needs, this study adapted the methodology according to the outline of Arksey and O'Malley $(2005,4)$ and informed by the refinements by Levac et al. $(2010,4)$ and Peters et al. 
(2015). The steps involved in the methodological framework include 1) identifying the research questions, 2) searching for studies, and 3) selecting relevant studies.

\subsection{Identifying the research questions}

Consistent with the context provided above, this paper departs from the assumption that informing policy makers on the effects of demand-oriented instruments is critical to understand how development and commercialization of innovations can be fostered. However, theoretical reviews on demand-oriented policies are limited to summarizing existing literature instead of conducting thorough reviews and identifying research gaps worth to investigate in future studies. To address this issue, this study aims at identifying an overarching framework showing the preferred research targets in the literature, particularly for demand-oriented instruments. This is important to uncover the missing attributes needed to frame effective innovation policies in view of the critical societal challenges. In this sense, the research questions guiding the scoping review are the following:

1. What is the sectoral focus of DS innovation policy?

2. What lessons can be learned from a country comparison?

3. What combinations of policy instruments have been analysed in the scholarly literature?

\subsection{Searching for relevant studies}

To identify relevant studies, the scoping team agreed upon time span, language, sources of literature, and search terms. The time span runs from 2000 to 2018. This period was chosen after preliminary readings helped identify the seminal studies on demand-oriented studies. Although previous studies exist, they lack the innovation focus that guides the review. Language of choice was English to assure replicability of the review as well as future 
extension by other researchers. Search was conducted in electronic databases, including Scopus and Web of Knowledge since they contain more high-quality journals than other databases and listings. The search terms were firstly defined to reflect the broad aspects of the demand-oriented perspective, innovation, and policy, and were refined after the scoping team gained a sense on the scope of the review. The search term 'demand-' was particularly challenging since initial searches resulted in extensive searches the broad discipline of economics beyond the focus on innovation policies. The database search string that was developed to guide this search is outlined in Table 1. Subsequently, the search terms were refined along with other inclusion criteria, outlined in Table 2.

Table 1. Database search string

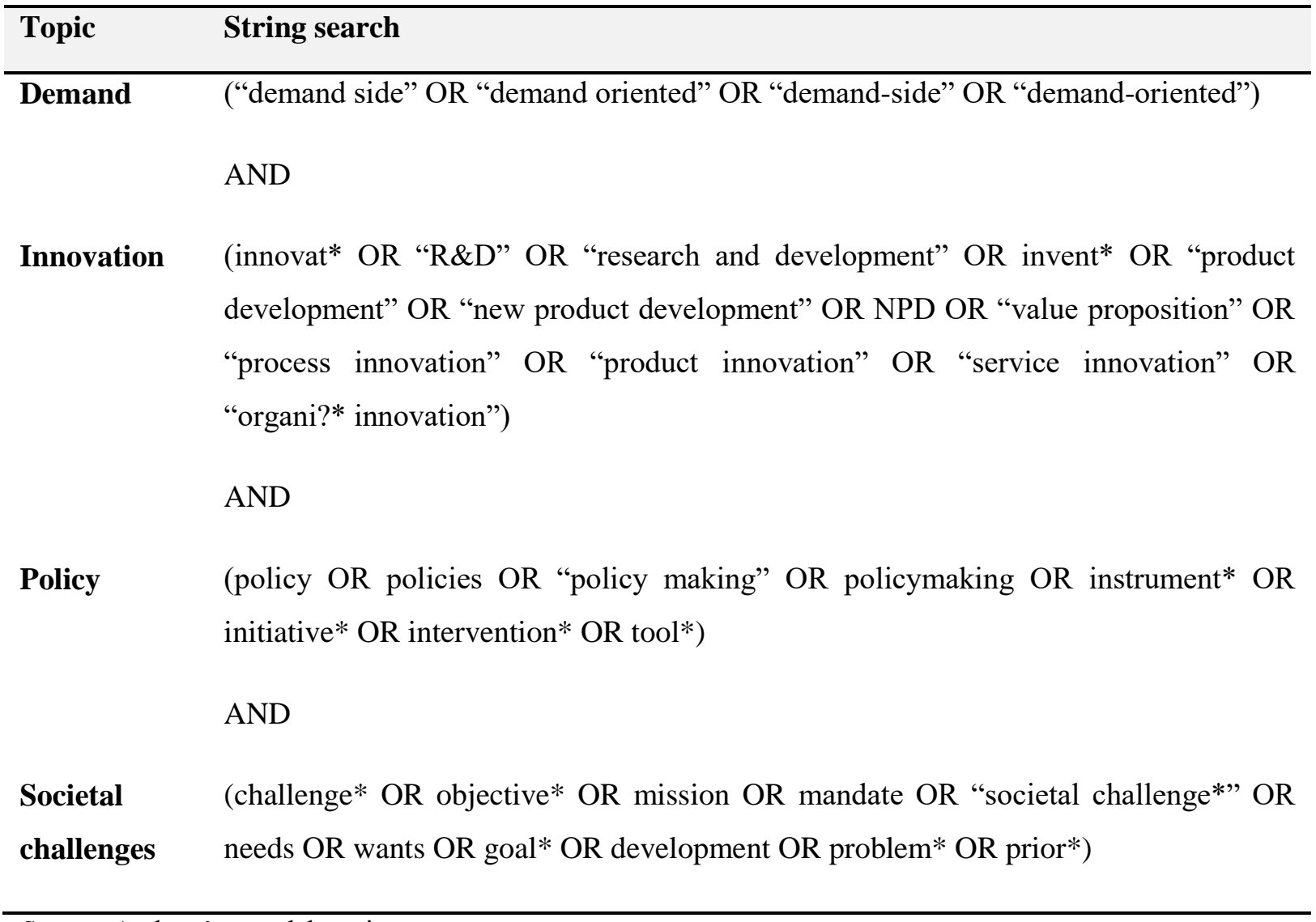

Source: Authors' own elaboration. 
Table 2. Inclusion and exclusion criteria for search refinement

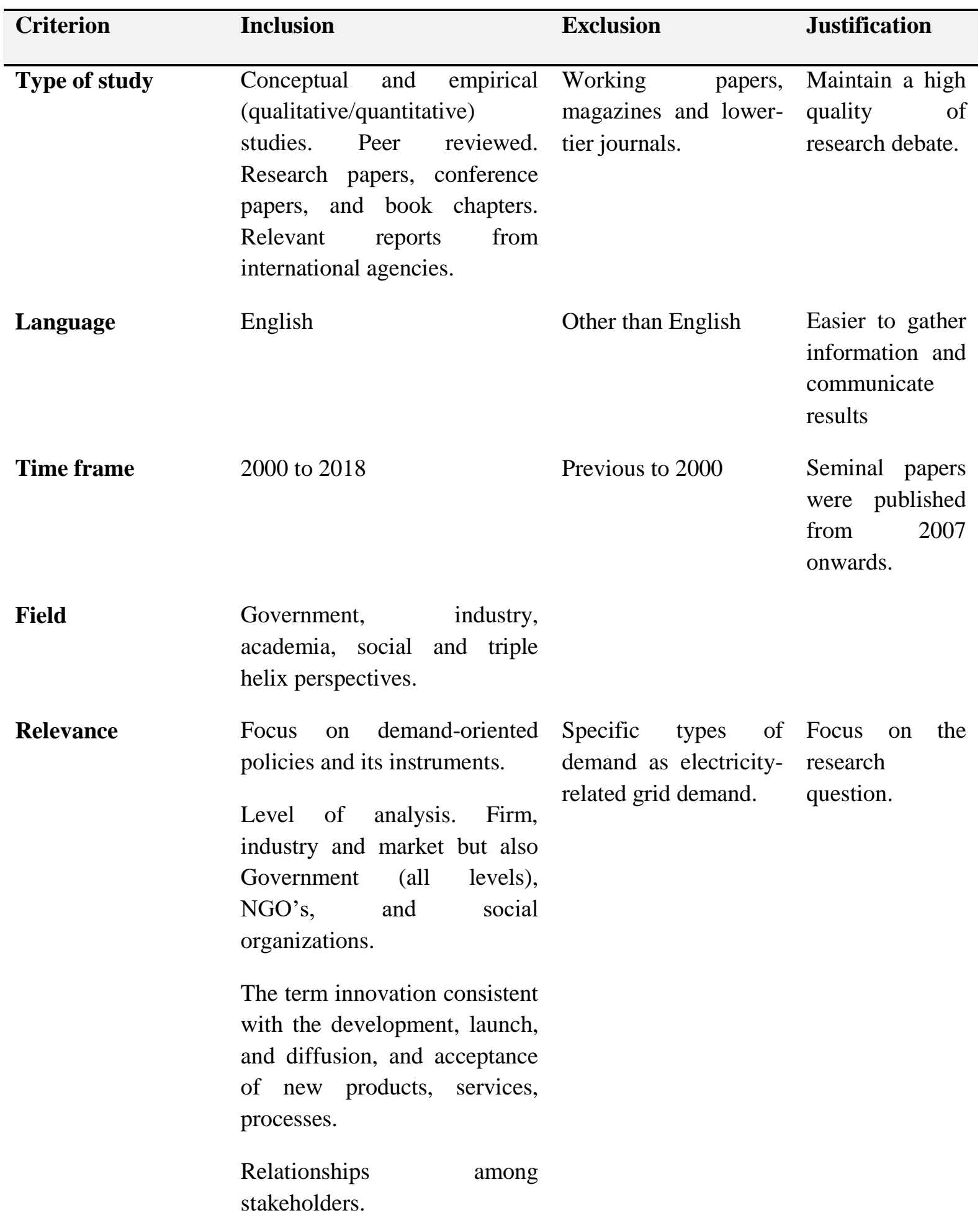

Source: Authors' own elaboration. 


\subsection{Selecting relevant studies}

According to the inclusion criteria discussed, the search resulted in 636 articles. Articles were screened by two members of the scoping team. After assessing title, abstracts, and key words, 78 articles were kept since article domain was in the scope of the review -innovation policy (see Appendix 1). Disagreements in the assessment were settled by the third member of the scoping team. Grey literature from preliminary searches was included to the final search number. Figure 1 illustrates the process of article selection.

Figure 1. Flow diagram for article selection. Source: Authors' own elaboration

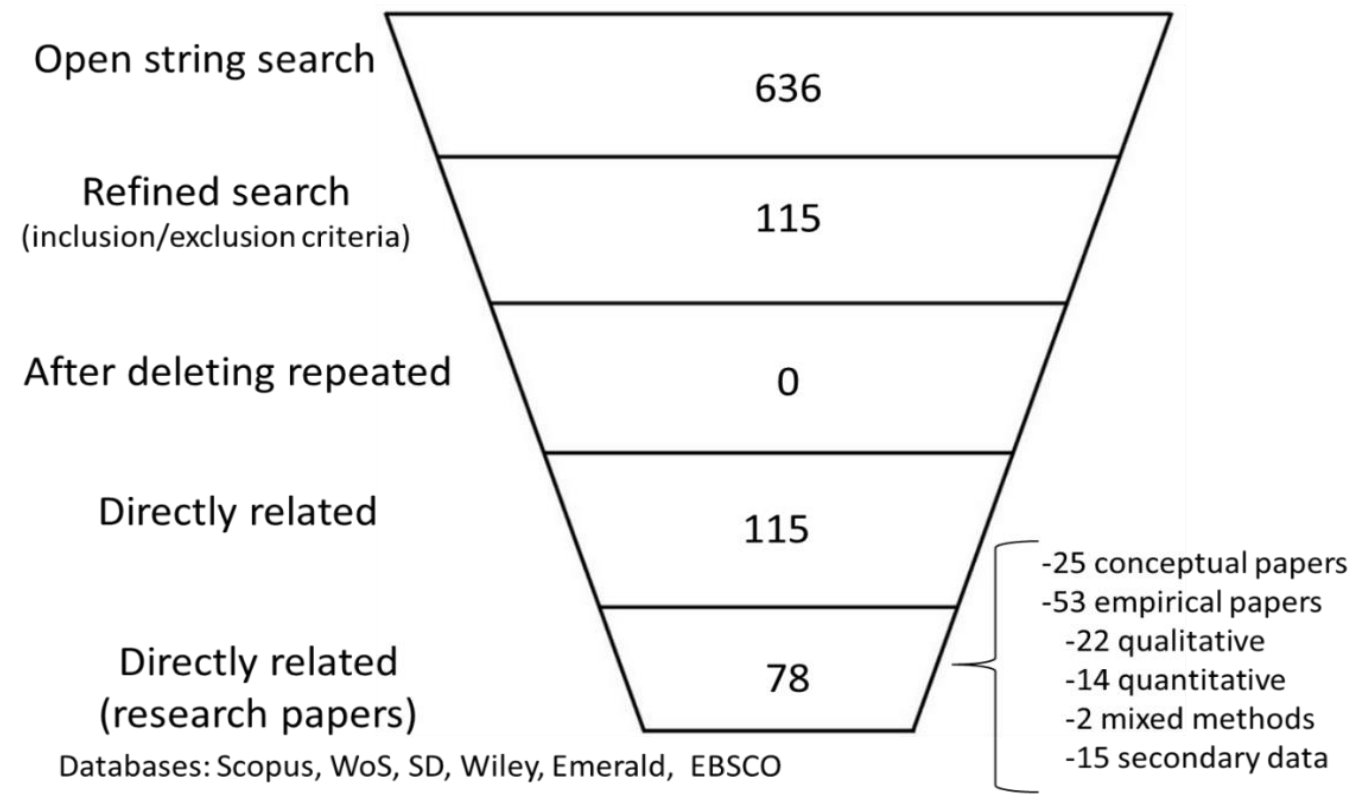

Source: Authors' own elaboration

\section{Thematic analysis of the literature}

This section analyses the main characteristics of the data. To chart the resulting number of articles, the scoping team assessed descriptive attributes of the articles by country, industrial sector, research objectives, and type of article (theoretical / empirical). A rubric was used to 
assess the core attributes of the articles, as robustness of theory, methodology, generalizability of results, and implications for practice.

From the 78 articles in the final review, 30 are conceptual papers that propose different models and frameworks to assess a number of policy and instruments. From the remaining 53 empirical papers, 22 refer to qualitative studies while only 14 papers include quantitative methodologies. Mixed methods are conducted in two papers. Qualitative research involves case studies mainly. A thematic classification of the papers by industry show that 10 paper addresses energy issues, five paper analyzes environmental technologies, five papers analyzes innovations in the pharmaceutical sector, three papers analyzes innovations related to electric automobiles, and three 3 papers refers to IT innovations. Urban issues are addressed in five papers and government policies are analyzed in by eight papers. The remaining 14 papers analyze issues in R\&D as well as macroeconomic issues related to such policies. Fig. 2 and 3 illustrates number of articles by country and by industry respectively.

Figure 2. Number of papers by country/ region

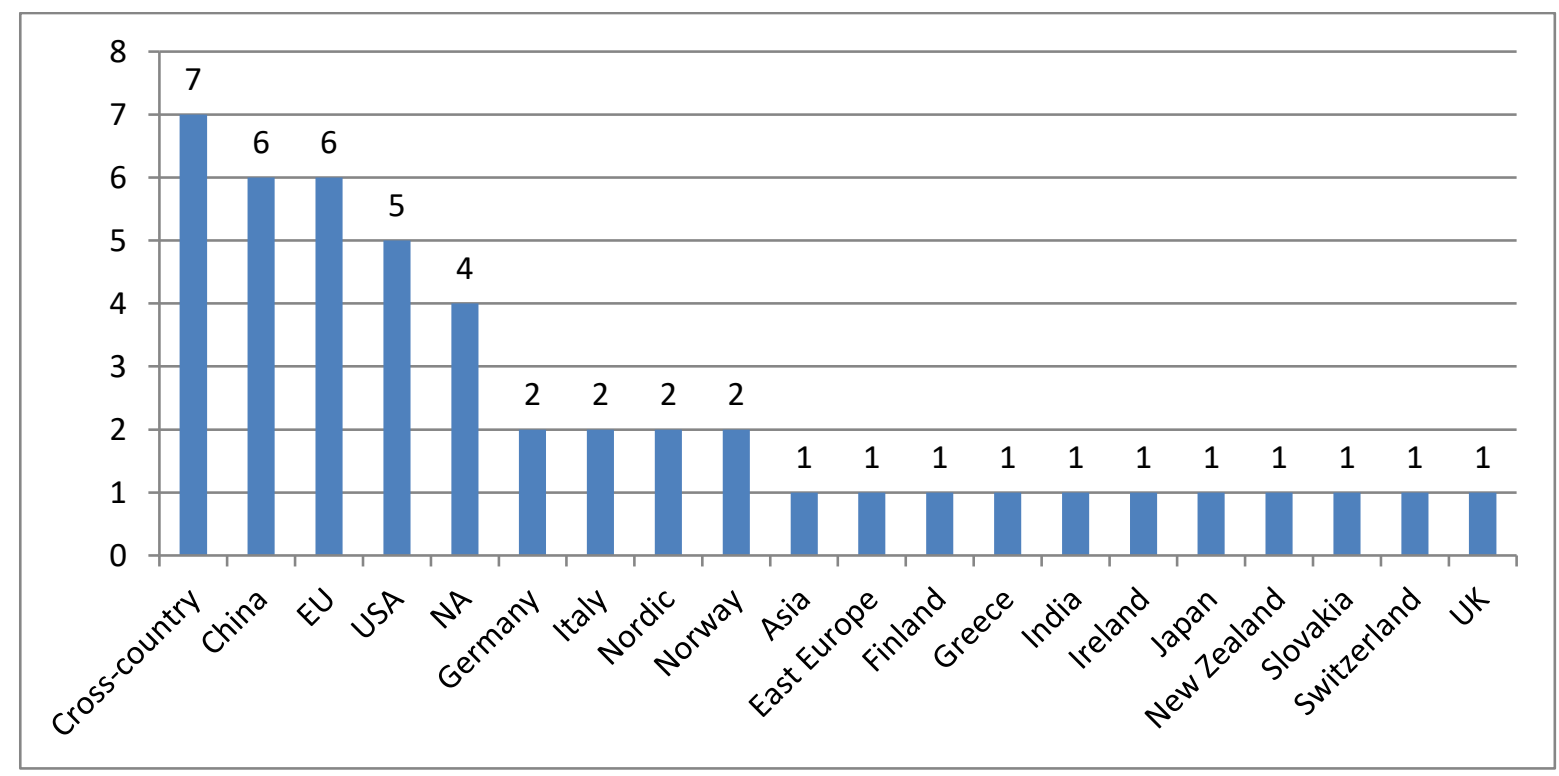

Source: Authors' own elaboration. 


\section{Journal of Evolutionary Studies in Business}

In particular, Fig. 2 shed light on the countries as unit of analysis for DS studies; crosscountry comparisons, along with China, European Union, and United States ranks the first places (NA: Country data not available). This is consistent with early calls to develop alternate approaches to innovation policies which were firstly made in the European Union.

As shown in Figure 1, though cross-country studies represent the majority of research, the innovation policy literature has targeted China, the European Union (EU) and the United States (USA) as main innovation policy cases. However, if individual European countries are added to EU cases, the number of innovation policy research papers totals around 17, outnumbering any other region in the world. This is a clear indicator of the European dominion of the innovation policy literature.

Figure 3. Articles by industry

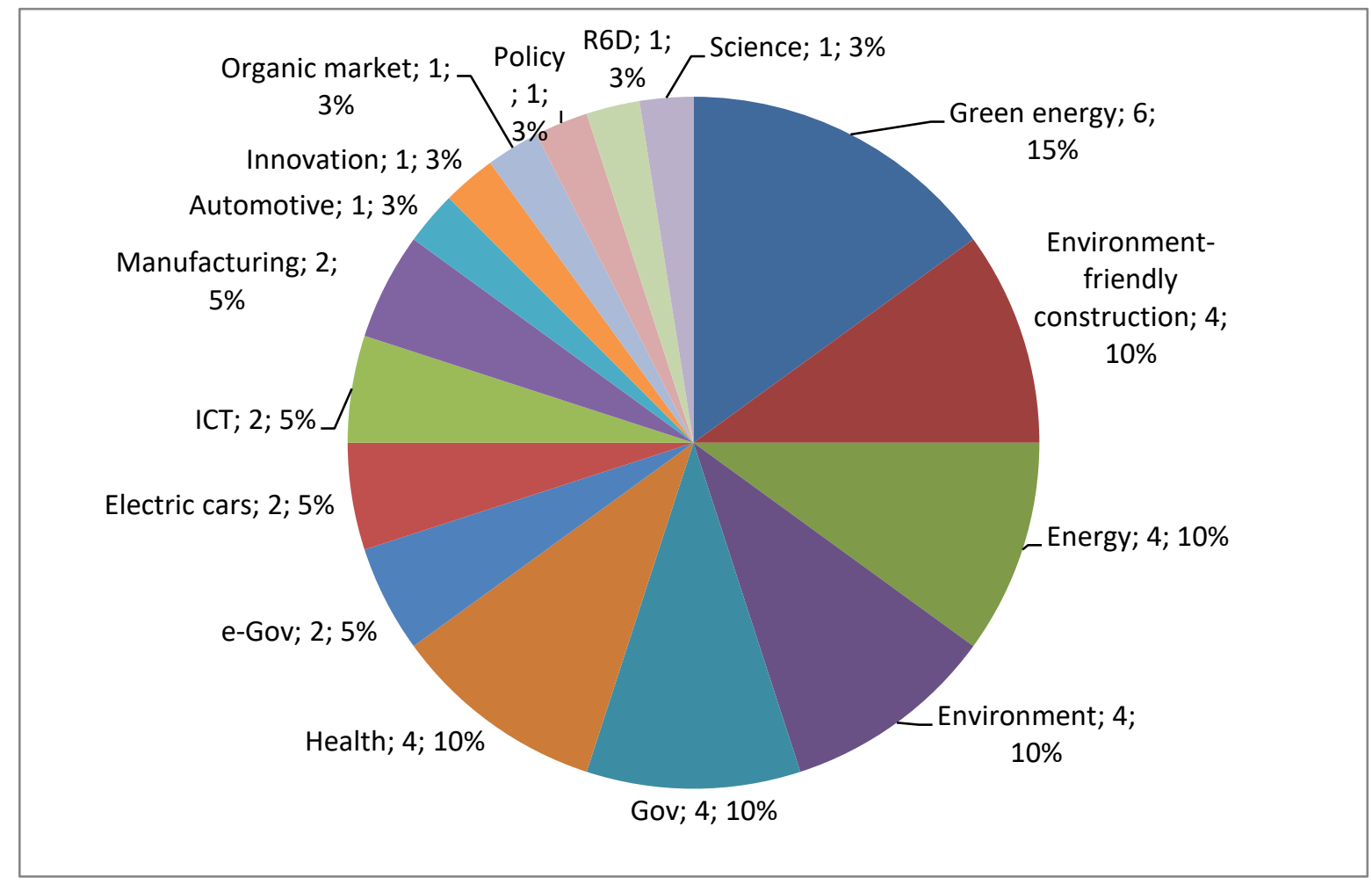

Source: Authors' own elaboration. 
From a sectoral perspective, Fig. 3 shows that most of existing research on DS policies refers to energy and sustainability issues. Most articles analyse innovation policies related to sustainability issues, namely, energy, environment-friendly construction, environmental solutions and clean-tech. Health and other government-related activities follow. This is in line with seminal papers which call or new policy approaches mainly to solve societal problems and also to fulfil mission-oriented innovative products.

\section{Findings}

In this section, we discuss key findings from the literature, which are exemplified from a regional, sectoral and tactical perspective; the latter referring to how different types of innovation policy instrument are combined to deliver outcomes that are more effective.

\subsection{The sectoral focus of demand-side innovation policy}

DS policies are expected to encourage immature markets (Jiang et al. 2018, 9). In our scoping review the effectiveness of DS instruments identified by authors were clearly related with certain economic sectors, but at the same time presented incomplete or adverse effects. For instance, in the generic pharmaceutical market, the effect of aggressive DS policies such as mandatory generic substitution, increased demand for generics, although at the same time it had adverse effects on competition, in that the lowest priced option captured the majority of sales, reducing the number of competitors (Kanavos 2014, 230).

In the transportation sector, DS policies such as regulatory frameworks or mandates have prompted public and private investment in low carbon vehicle technologies, - these policies have been a key determinant of Toyota's investment in hybrid electric vehicles (Whitmarsh and Köhler 2010, 437). Kesidou and Demirel $(2012,867)$ found similar effects in the eco- 
innovation sector. Regarding green product innovation, the literature indicates that SS subsidies and voluntary agreements have positive effects, while taxes and regulations have negative effects on product innovation (Stucki et al. 2018, 251). Nevertheless, government regulation, although crucial for stimulating investment in innovations, is still insufficient and does not necessarily lead to the adoption of innovation (Kesidou and Demirel 2012, 866). Similar to the DS policies, SS instruments have shown little effectiveness in the adoption of innovation by customers, particularly in the transport sector (Whitmarsh and Köhler 2010, 434).

Another DS instrument, the Public Procurement of Innovations (PPI) adopted a number of definitions according to local contexts, for example, Public end Users Driven Technological Innovation - PDTI (Puig-Pey et al. 2017, 167) and Green Public Procurement of Innovations or GPPI (Peñate-Valentín et al. 2018, 408). Regardless of the specific definition, the majority of case studies converge in that PPI influence the development and diffusion of innovations. Exemplary cases include the CERN research center (Landoni 2017, 587) in which the industry - R\&D center interface has incentivized some innovations. Pickernell et al. (2011, 650) argue that PPI has a role on local and regional economic development by engaging small and medium enterprises at varying levels of territorial government scales. At the city level, evidence shows the benefits from implementing DS policies in terms of market creation and urban competitiveness (Lember et al. 2011, 1385). A similar case is offered by European cities that shared a list of urban needs in relation with urban robotic technologies whose development was successfully fulfilled through PPI (Puig-Pey et al. 2017, 169). An interesting case is the role of catalogues of technology-based products as an indicator of what products need to be developed and commercialized in China (Li and Georghiou 2016, 10). 
The previous discussion of literature shows that industries unrelated to energy and sustainability may also benefit from implementing DS innovation policies with a number of instruments to assess the extent to which innovation is enhanced. Hence, we propose the following research proposition:

RP1: The implementation of DS instruments in high impact industries (e.g. software, aerospace, or genomics) enhances innovation and technology-intensive outputs, and the outcome is heterogeneous across industries.

\subsection{Country comparison}

In the scoping review, we observe differences in the implementation of innovation policies across countries. It seems that, as Jang et al. $(2015,12593)$ assert, the choice of instruments to support innovation is related to a country's level of development. For instance, the innovation policies in United States, Germany, Japan, Denmark, China, Singapore and the Republic of Korea include both push technology (SS) and pull market (DS) instruments in balance (Zhi 2014, 314 ; Buen 2006, 3888; Jang et al 2015, 12594). Germany and Japan place less emphasis on the SS compared with United States and China; this later country stands out for being a quick learner that follows international policy experience (Zhi 2014, 314). A limited extent of innovation, especially in the wind technology has been reported in Norway, which has a short-term focus on the policy instruments and lacks DS measures, despite being a developed country (Buen 2006, 3896).

From the scoping review, it is clear that studies focus on developed and industrialized countries, clearly noticeable by the fact that data from developing countries is not always available and is less reliable (Wesseling 2016, 4). Nevertheless, some scholars such as Jang et al. $(2015,12591)$ have analyzed innovation policies in 17 Asian countries, including developing economies such as Thailand, Indonesia, Malaysia, and the Philippines. They 
observed that most of these countries just follow the trend of innovation policies implemented by developed nations. Other less advanced countries such Myanmar, Lao PDR, Brunei Darussalam, and Cambodia lack SS and DS policy instruments, and just rely on technology transfers to foster innovation (Jang et al. 2015, 12608).

Latin American countries have had limited success in innovation policies by only "cutting and pasting" those policies implemented in OECD countries without any consideration the local context (Arocena and Sutz 2010, 573). In this sense, Arocena and Sutz $(2010,574)$ indicates that SS instruments, e.g. tax reductions and funds for innovations, have been more frequently adopted than DS instruments like public procurement, which has been hardly adopted in the region.

Clearly, innovation policies implemented in advanced countries have paved the way (Kuhlmann and Rip 2018, 448-450), and there is need to develop research avenues that aim to understand the potential of DS instruments in the contexts of emerging countries. While DS policies have been enacted in developed, economically stable but low-growth countries, little is known of the effects of such policy approaches in developing countries, which exhibit a different setting in socio-economic-political dimensions. Therefore, we propose:

RP2: Adapting DS policies and their associated instruments to the Latin American setting would complement the standard SS instruments already in place in such a way that local and multinational companies would increase innovation and technologyintensive output.

\subsection{Combinations of policy instruments}

SS innovation policies tend to focus on firm-level capabilities and economic outcomes, nevertheless, some authors claim that their effectiveness and distributional consequences are still unclear (Hanley and Douglass 2014, 228). Subsidies have also gained scholarly 
disapproval as they support R\&D activity but not successful enterprising (Jiang et al. 2018, 9). Additionally, subsidies can generate distortions in business health perception, including the reliance disease and wrong financial reporting (Jiang et al. 2018, 9).

According to the literature, the effectiveness of SS and DS policies alone has been repeatedly questioned. For instance, in the study developed by Karmarkar-Deshmukh and Carl (2009, 18) about ethanol, government subsidies and federal tax credits showed to be effective to encourage the production; nevertheless, this increase in production has led to a decrease in patents. In this sector, government research grants and awards have proved to be more effective to increase patents (Karmarkar-Deshmukh and Carl 2009, 36-38).

These heterogeneous results on the effectiveness of SS can be explained because of the emphasis on product or process innovation - more positive effects are observed on process innovation than on product innovation - (Stucki et al. 2018, 255). The characteristics of the innovation players can help also to explain this variation, since negative policy effects were observed for "typical innovators" (those who develop products that are new to the firm), but not for "technological leaders" (those who create innovations that are new to the market) (Stucki et al. 2018, 255). Hence, an appropriate combination of SS and DS policies appear to be more effective, according to the literature.

On the other hand, implementing demand-oriented instruments requires clear innovation policy transition strategies (Alkemade et al. 2011, 127-128), coupled with a systemic approach in which technology development paths are aligned with all other government policies, such as the industrial and economic policy. The literature acknowledges that PPI is subject to contextual variables as policy regulation, interpretation, and interaction between tender participants and the government (Dale-Clough 2015, 18-21). Similarly, instruments 
from SS-oriented policies may interact with PPI to positively develop green innovations (Peñate-Valentín et al. 2018, 408-409).

From the literature review that the design of effective innovation policies require considerations for both supply and demand perspectives, whose applications needs to be context-dependent, and designed according to the stage of innovation and the desired effect. Hence, the development of an appropriate innovation policy requires a deeper understanding of those contextual elements that determine strengths and weaknesses of selected policies.

Finally, recommendations for establishing the appropriate policy mix involve considerations about the evolving stage of the sector: while SS policies are more functional in early stages, in the mature stages, DS policies should gradually replace them. Once the industry enters a selfbalanced phase, the withdrawal of these policy instruments should be considered (Zhi 2014, 318). Denmark and Germany are good models of balancing an innovation policy mix, according to the sectoral stage (Buen 2006, 3889; Zhi 2014, 318). However, the evaluation of innovation policy has been restricted to SS policies, as there is a research gap around DS indicators, complicating the identification of successful DS measures (Edler et al. 2012, 44). The previous discussion calls for an assessment of interaction effects of instruments. Hence, we propose:

RP3: The interaction of DS and SS instruments leads to higher innovation and technology-intensive output.

\section{Conclusion}

This study has reviewed key scholarly literature about innovation policy, particularly DS innovation policy and advances three research proposals. This type of policies is guided by government-defined interests around innovation development along with creating a demand 
for such innovations. Beyond capacity-building and technology-push models, DS innovation policy accepts directionality based on contextual understanding of societal challenges.

However, the literature has mainly analysed DS policy cases in more developed economies, with some exceptions. Europe stands out as the focus of academic research in the topic, indicating regional concerns about problem-solving policies, especially sustainability and energy-related issues. Our analysis has been systematic from a methodological perspective and has been classified as a scoping review in consideration to the research questions posed in this article. This study has indicated the inclination of scholarly research around the DS innovation policy from a sectoral, geographical and tactical approach.

Cases of policy results at the sectoral and geographical level have been also provided, emphasizing varied degrees of success, leading to tactical recommendations around mixed policies, whose application depends on context and the maturity of the sector. Given the limited experiences of DS innovation policy application in developing economies, this research identifies the need to build a research agenda around DS, mixed innovation policies and related instruments in developing countries. Noteworthy, some studies advice for a combination at different degrees of DS and SS policies - a policy mix - which may provide deeper insights in achieving higher levels of innovation and fulfilment of societal challenges. In our review, only a handful of studies critically analyses such policy mix. Hence, this research avenue remains open to academic debate and further research.

This research has implications for public policy, such as inviting researchers and policy practitioners to assess the experience of advanced economies around the implementation of DS innovation policies, including DS-SS mixed models. Particularly, developing economies such as Latin American's can take advantage of these experiences to design purposive DS 
innovation policies adapted to their local contexts. DS or mixed innovation policy adoption should include a deep understanding of Latin American's priorities and conditions, demanding a positive attitude towards risk. Managerial perceptions and data from a nationalwide survey in Mexico on research and technological development (ESIDET) may serve as a basis for further research to address the research questions advanced in this paper. Such studies are underway.

\section{Acknowledgements}

This project is funded by grant CONACYT PN2016-01.3218

\section{References}

Alkemade, Floorje, Marko P. Hekkert, and Simona O. Negro. 2011. "Transition policy and innovation policy: friends or foes?" Environmental Innovation and Societal Transitions 1 (1): 125-129.

Acs, Zoltan J. 2008. Foundations of high impact entrepreneurship. Foundations and trends in entrepreneurship. Now Publishers Inc.

Acs, Zoltan. J. 2010. "High-Impact entrepreneurship." In Handbook of entrepreneurship research: An interdisciplinary survey and introduction, edited by Acs, Zoltan.J., and David B. Audretsch, 165-82. New York: Springer New York.

Acs, Zoltan. J., and Paulo Guilherme Correa. 2015. Identifying obstacles to high impact entrepreneurship in Latin America. The Innovation Policy Platform World Bank.

Anisimov, Ivan. 2015. "Innovation policy features in the OECD countries." Baltic Journal of Economic Studies 1 (1): 4-9.

Arksey, Hilary, and Lisa O’Malley. 2005. "Scoping studies: towards a methodological framework." International Journal of Social Research Methodology: Theory and Practice 8(1): 19-32.

Arocena, Rodrigo, and Judith Sutz. 2010. "Weak knowledge demand in the South: learning divides and innovation policies." Science and Public Policy 37 (8): 571-582.

Buen, Jorund. 2006. "Danish and Norwegian wind industry: The relationship between policy instruments, innovation and diffusion.” Energy Policy 34 (18): 3887-3897. 
Bugge, Marcus M., Lars Coenen, and Are Branstad. 2018. "Governing socio-technical change: Orchestrating demand for assisted living in ageing societies." Science and Public Policy 45 (4): $468-479$.

Cimoli, Mario. 2013. Developing innovation systems: Mexico in a global context. Routledge. ISBN 1136547169 .

Dale-Clough, Lisa. 2015. "Public procurement of innovation and local authority procurement: Procurement modes and framework conditions in three European cities." Innovation: The European Journal of Social Science Research 28 (3): 220-242.

Edler, Jakob, and Jan Fagerberg. 2017. "Innovation policy: what, why, and how." Oxford Review of Economic Policy 33 (1): 2-23.

Edler, Jakob, Luke Georghiou, Knut Blind, and Elvira Uyarra. 2012. "Evaluating the demand side: New challenges for evaluation." Research Evaluation 21 (10): 33-47.

Edquist, Charles. 2011. "Design of innovation policy through diagnostic analysis: identification of systemic problems (or failures).” Industrial and Corporate Change 20 (6): 1725-1753.

Hanley, Caroline, and Michael T. Douglass. 2014. "High road, low road, or off road? Economic development strategies in the American states." Economic Development Quarterly 28 (3): 220229.

Henrekson, Magnus, and Michael Stenkula. 2010. "Entrepreneurship and public policy." In Handbook of entrepreneurship research, edited by Zontan, Acs, and David B. Audretsch, 595-637. New York: Springer.

Kanavos, Panos. 2014. "Measuring performance in off-patent drug markets: A methodological framework and empirical evidence from twelve EU member states." Health Policy 118 (2): 229241.

Karmarkar-Deshmukh, Rupa, and Carl E. Pray. 2009. "Private sector innovation in biofuels in the United States: induced by prices or policies?" AgBioForum 12 (1): 1-8.

Kesidou, Effie, and Pelin Demirel. 2012. "On the drivers of eco-innovations: Empirical evidence from the UK." Research Policy 41 (5): 862-870.

Kuhlmann, Stefan, and Arie Rip. 2018. "Next-generation innovation policy and grand challenges." Science and Public Policy 45 (4): 448-454.

Jang, Eun Kyung, Mi Sun Park, Tae Woo Roh, and Ki Hoo Han. 2015. "Policy instruments for ecoinnovation in Asian countries." Sustainability 7 (9): 12586-12614.

Jiang, Cailou, Ying Zhang, Maoliang Bu, and Weishu Liu. 2018. "The effectiveness of government subsidies on manufacturing innovation: Evidence from the new energy vehicle industry in China." Sustainability 10 (6):1692. 
Landoni, Matteo. 2017. "Innovation policy in progress. Institutional intermediation in public procurement of innovation: satellite telecommunications in Italy." $R \& D$ Management 47 (4): 583-594.

Langer, Laura. 2001. "The consequences of state economic development strategies on income distribution in the American states, 1976 to 1994." American Politics Research 29 (4): 392-415.

Lember, Veiko, Tarmo Kalvet, and Rainer Kattel. 2011. "Urban competitiveness and public procurement for innovation." Urban Studies 48 (7): 1373-1395.

Levac, Danille, Heather Colquhoun, and Kelly O'Brien. 2010. "Scoping studies: advancing the methodology." Implementation Science 5 (1):69.

Li, Yanchao, and Luke Georghiou. 2016. "Signaling and accrediting new technology: Use of procurement for innovation in China." Science and Public Policy 43 (3): 338-351.

Lundvall, Bengt-Ake, K. J. Joseph, Cristina Chaminade, and Jan Vang, eds. 2011. Handbook of innovation systems and developing countries: Building domestic capabilities in a global setting. Edward Elgar Publishing. ISBN 1849803420.

Peñate-Valentín, María Concepción, Angeles Pereira, and María del Carmen Sánchez-Carreira. 2018. "Servitization in the public sector: A framework for energy service companies." In Practices and tools for servitization, edited by Kohtamäki Marco, Tim Baines, Rodrigo Rabetino, and Ali Z. Bigdeli. Palgrave Macmillan, Cham.

Peters, Micah, Christina Godfrey, Khalil Hanan, Patricia McInerney, Deborah Parker, and Cassia Baldini Soares. 2015. "Guidance for conducting systematic scoping reviews." International Journal of Evidence-based Healthcare 13 (3): 141-146.

Pickernell, David, Adrian Kay, Gary Packham, and Christopher Miller. 2011. "Competing agendas in public procurement: An empirical analysis of opportunities and limits in the UK for SMEs." Environment and Planning C: Government and Policy 29 (4): 641-658.

Priem, Richard, Sali Li, and Jon Carr. 2012. "Insights and new directions from demand-side approaches to technology innovation, entrepreneurship, and strategic management research." Journal of Management 38 (1): 346-374.

Puig-Pey, Anna, Yolanda Bolea, Antoni Grau, and Josep Casanovas. 2017. "Public entities driven robotic innovation in urban areas." Robotics and Autonomous Systems 92:162-172.

Stucki, Tobias, Martin Woerter, Spyros Arvanitis, Michael Peneder, and Christian Rammer M. 2018. "How different policy instruments affect green product innovation: A differentiated perspective." Energy Policy 114 (3): 245-261.

Wesseling, Joeri H. 2016. "Explaining variance in national electric vehicle policies." Environmental Innovation and Societal Transitions 21:28-38. 


\section{Journal of Evolutionary Studies in Business}

Whitmarsh, Lorraine, and Jonathan Köhler. 2010. "Climate change and cars in the EU: the roles of auto firms, consumers, and policy in responding to global environmental change." Cambridge Journal of Regions, Economy and Society 3 (3): 427-441.

Zhi, Quian, Honghang Sun, Yanxi Li, Yurui Xu, and Jun Su. 2014. "China's solar photovoltaic policy: An analysis based on policy instruments." Applied Energy 129 (15): 308-319. 


\section{Appendix 1. References in the Scoping Review}

\begin{tabular}{|c|c|c|c|c|}
\hline$\#$ & Authors & Year & Title & Journal / Conference \\
\hline 1 & Magdaniel, F C & 2016 & $\begin{array}{l}\text { Technology campuses and cities: A study on the relation } \\
\text { between innovation and the built environment at the urban area } \\
\text { level }\end{array}$ & $\begin{array}{l}\text { A+BE Architecture and the Built } \\
\text { Environment }\end{array}$ \\
\hline 2 & $\begin{array}{l}\text { Karmarkar- } \\
\text { Deshmukh, R }\end{array}$ & 2009 & $\begin{array}{l}\text { Private sector innovation in biofuels in the United States: } \\
\text { Induced by prices or policies? }\end{array}$ & AgBioForum \\
\hline 3 & TÕnurist, $\mathrm{P}$ & 2016 & $\begin{array}{l}\text { STATE OWNED ENTERPRISES AS INSTRUMENTS OF } \\
\text { INNOVATION POLICY }\end{array}$ & $\begin{array}{l}\text { Annals of Public and Cooperative } \\
\text { Economics }\end{array}$ \\
\hline 4 & Qiang, Zhi & 2014 & $\begin{array}{l}\text { China's solar photovoltaic policy: An analysis based on } \\
\text { policy instruments }\end{array}$ & APPLIED ENERGY \\
\hline 5 & Anisimov, Ivan & 2015 & $\begin{array}{l}\text { INNOVATION POLICY FEATURES IN THE OECD } \\
\text { COUNTRIES }\end{array}$ & $\begin{array}{l}\text { BALTIC JOURNAL OF ECONOMIC } \\
\text { STUDIES }\end{array}$ \\
\hline 6 & Minglei, D & 2013 & $\begin{array}{l}\text { Research on the technological innovation strategy and policies } \\
\text { of china's new urbanization }\end{array}$ & BioTechnology: An Indian Journal \\
\hline 7 & Doran, J & 2016 & $\begin{array}{l}\text { The Importance of the Diverse Drivers and Types of } \\
\text { Environmental Innovation for Firm Performance }\end{array}$ & Business Strategy and the Environment \\
\hline 8 & Whitmarsh, L & 2010 & $\begin{array}{l}\text { Climate change and cars in the EU: The roles of auto firms, } \\
\text { consumers, and policy in responding to global environmental } \\
\text { change }\end{array}$ & $\begin{array}{l}\text { Cambridge Journal of Regions, } \\
\text { Economy and Society }\end{array}$ \\
\hline 9 & Janssen, M A & 2000 & $\begin{array}{l}\text { Climate change policy targets and the role of technological } \\
\text { change }\end{array}$ & Climatic Change \\
\hline 10 & Hanley, Caroline & 2014 & $\begin{array}{l}\text { High Road, Low Road, or Off Road? Economic Development } \\
\text { Strategies in the American States }\end{array}$ & $\begin{array}{l}\text { ECONOMIC DEVELOPMENT } \\
\text { QUARTERLY }\end{array}$ \\
\hline 11 & Baraškina, Irēna & 2009 & $\begin{array}{l}\text { Development of Organic Agriculture in Europe: from Origins to } \\
\text { the Current Level of Life-Cycle. }\end{array}$ & $\begin{array}{l}\text { Economic Science for Rural } \\
\text { Development Conference Proceedings }\end{array}$ \\
\hline 12 & Zhang, $\mathrm{H}$ & 2017 & $\begin{array}{l}\text { Has government intervention effectively encouraged the use of } \\
\text { waste cooking oil as an energy source? Comparison of two } \\
\text { Chinese biofuel companies }\end{array}$ & 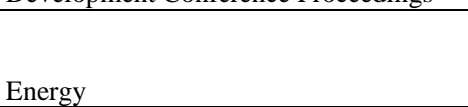 \\
\hline 13 & Mundaca, L & 2018 & Demand-side approaches for limiting global warming to $1.5^{\circ} \mathrm{C}$ & Energy Efficiency \\
\hline 14 & Banales-Lopez, S & 2002 & $\begin{array}{l}\text { Public policy for energy technology innovation - A historical } \\
\text { analysis of fluidized bed combustion development in the USA }\end{array}$ & ENERGY POLICY \\
\hline 15 & Christiansen, A C & 2002 & $\begin{array}{l}\text { New renewable energy developments and the climate change } \\
\text { issue: A case study of Norwegian politics }\end{array}$ & Energy Policy \\
\hline 16 & Kimura, $\mathrm{O}$ & 2010 & $\begin{array}{l}\text { Public R\&D and commercialization of energy-efficient } \\
\text { technology: A case study of Japanese projects }\end{array}$ & Energy Policy \\
\hline 17 & Lin, Chen-Chun & 2013 & $\begin{array}{l}\text { A comparison of innovation policy in the smart grid industry } \\
\text { across the pacific: China and the USA }\end{array}$ & ENERGY POLICY \\
\hline 18 & Stucki, T & 2018 & $\begin{array}{l}\text { How different policy instruments affect green product } \\
\text { innovation: A differentiated perspective }\end{array}$ & Energy Policy \\
\hline 19 & kuzemko, C & 2017 & $\begin{array}{l}\text { Policies, politics and demand side innovations: The untold story } \\
\text { of Germany's energy transition }\end{array}$ & Energy Research and Social Science \\
\hline 20 & pickernell, D & 2011 & $\begin{array}{l}\text { Competing agendas in public procurement: An empirical } \\
\text { analysis of opportunities and limits in the UK for SMEs }\end{array}$ & $\begin{array}{l}\text { Environment and Planning C: } \\
\text { Government and Policy }\end{array}$ \\
\hline 21 & baldock, Robert & 2016 & $\begin{array}{l}\text { An assessment of the business impacts of the UK's Enterprise } \\
\text { Capital Funds }\end{array}$ & $\begin{array}{l}\text { ENVIRONMENT AND PLANNING C- } \\
\text { GOVERNMENT AND POLICY }\end{array}$ \\
\hline 22 & Groba, F & 2015 & $\begin{array}{l}\text { Chinese Renewable Energy Technology Exports: The Role of } \\
\text { Policy, Innovation and Markets }\end{array}$ & $\begin{array}{l}\text { ENVIRONMENTAL \& RESOURCE } \\
\text { ECONOMICS }\end{array}$ \\
\hline 23 & wesseling, $\mathrm{J} \mathrm{H}$ & 2016 & Explaining variance in national electric vehicle policies & $\begin{array}{l}\text { Environmental Innovation and Societal } \\
\text { Transitions }\end{array}$ \\
\hline 24 & nemet, G F & 2018 & Negative emissions - Part 3: Innovation and upscaling & Environmental Research Letters \\
\hline 25 & radosevic, $\mathrm{S}$ & 2009 & $\begin{array}{l}\text { Research and development, competitiveness and European } \\
\text { integration of South Eastern Europe }\end{array}$ & Europe - Asia Studies \\
\hline 26 & hunt, Richard A & 2018 & $\begin{array}{l}\text { An opportunity space odyssey: historical exploration of } \\
\text { demand-driven entrepreneurial innovation }\end{array}$ & $\begin{array}{l}\text { EUROPEAN JOURNAL OF } \\
\text { INNOVATION MANAGEMENT }\end{array}$ \\
\hline 27 & Georghiou, L & 2011 & $\begin{array}{l}\text { From priority-setting to articulation of demand: Foresight for } \\
\text { research and innovation policy and strategy }\end{array}$ & Futures \\
\hline 28 & warnke, $\mathrm{P}$ & 2016 & $\begin{array}{l}\text { Small seeds for grand challenges-Exploring disregarded seeds } \\
\text { of change in a foresight process for RTI policy }\end{array}$ & Futures \\
\hline 29 & Grabowski, $\mathrm{H}$ & 2005 & $\begin{array}{l}\text { Perspective: Encouraging the development of new vaccines - } \\
\text { R\&D subsidies for new drugs to treat rare diseases are much } \\
\text { larger than those for new vaccines to prevent more common } \\
\text { diseases }\end{array}$ & Health Affairs \\
\hline 30 & kanavos, Panos & 2014 & $\begin{array}{l}\text { Measuring performance in off-patent drug markets: A } \\
\text { methodological framework and empirical evidence from twelve } \\
\text { EU Member States }\end{array}$ & HEALTH POLICY \\
\hline
\end{tabular}




\begin{tabular}{|c|c|c|c|c|}
\hline$\#$ & Authors & Year & Title & Journal / Conference \\
\hline 31 & $\mathrm{Hu}$, Jia & 2016 & $\begin{array}{l}\text { Pharmaceutical pricing and reimbursement in China: When the } \\
\text { whole is less than the sum of its parts }\end{array}$ & HEALTH POLICY \\
\hline 32 & arora, $\mathrm{A}$ & 2015 & Public support for technical advance: The role of firm size & Industrial and Corporate Change \\
\hline 33 & leimbach, $\mathrm{T}$ & 2010 & Assessing national policies to support software in Europe & Info \\
\hline 34 & aberg, Susanne & 2015 & Does CERN procurement result in innovation? & $\begin{array}{l}\text { INNOVATION-THE EUROPEAN } \\
\text { JOURNAL OF SOCIAL SCIENCE } \\
\text { RESEARCH }\end{array}$ \\
\hline 35 & dale-Clough, Lisa & 2015 & $\begin{array}{l}\text { Public procurement of innovation and local authority } \\
\text { procurement: procurement modes and framework conditions in } \\
\text { three European cities }\end{array}$ & $\begin{array}{l}\text { INNOVATION-THE EUROPEAN } \\
\text { JOURNAL OF SOCIAL SCIENCE } \\
\text { RESEARCH }\end{array}$ \\
\hline 36 & lember, Veiko & 2015 & Quo vadis public procurement of innovation? & $\begin{array}{l}\text { INNOVATION-THE EUROPEAN } \\
\text { JOURNAL OF SOCIAL SCIENCE } \\
\text { RESEARCH }\end{array}$ \\
\hline 37 & neck, $\mathrm{R}$ & 2018 & $\begin{array}{l}\text { How to Achieve the Take-off into Sustained Growth: A Case } \\
\text { Study for Slovenia }\end{array}$ & $\begin{array}{l}\text { International Advances in Economic } \\
\text { Research }\end{array}$ \\
\hline 38 & su, Y.-S. & 2016 & $\begin{array}{l}\text { An assessment of innovation policy in Taiwan's electric vehicle } \\
\text { industry }\end{array}$ & $\begin{array}{l}\text { International Journal of Technology } \\
\text { Management }\end{array}$ \\
\hline 39 & sartorius, $\mathrm{C}$ & 2008 & $\begin{array}{l}\text { Promotion of stationary fuel cells on the basis of subjectively } \\
\text { perceived barriers and drivers }\end{array}$ & Journal of Cleaner Production \\
\hline 40 & rizzi, F & 2014 & $\begin{array}{l}\text { Environmental value chain in green SME networks: The threat } \\
\text { of the Abilene paradox }\end{array}$ & Journal of Cleaner Production \\
\hline 41 & rainville, Anne & 2017 & $\begin{array}{l}\text { Standards in green public procurement - A framework to } \\
\text { enhance innovation }\end{array}$ & $\begin{array}{l}\text { JOURNAL OF CLEANER } \\
\text { PRODUCTION }\end{array}$ \\
\hline 42 & eisenberg, Rebecca S & 2017 & Promoting healthcare innovation on the demand side & $\begin{array}{l}\text { JOURNAL OF LAW AND THE } \\
\text { BIOSCIENCES }\end{array}$ \\
\hline 43 & spulber, D F & 2013 & $\begin{array}{l}\text { How do competitive pressures affect incentives to innovate } \\
\text { when there is a market for inventions? }\end{array}$ & Journal of Political Economy \\
\hline 44 & Gambardella, A & 2017 & The user innovation paradigm: Impacts on markets and welfare & Management Science \\
\hline 45 & Edler, Jakob & 2017 & Innovation policy: what, why, and how & $\begin{array}{l}\text { OXFORD REVIEW OF ECONOMIC } \\
\text { POLICY }\end{array}$ \\
\hline 46 & Landoni, Matteo & 2017 & $\begin{array}{l}\text { Innovation policy in progress. Institutional intermediation in } \\
\text { public procurement of innovation: satellite telecommunications } \\
\text { in Italy }\end{array}$ & R \& D MANAGEMENT \\
\hline 47 & Edler, J & 2012 & Evaluating the demand side: New challenges for evaluation & Research Evaluation \\
\hline 48 & Edler, J & 2007 & $\begin{array}{l}\text { Public procurement and innovation-Resurrecting the demand } \\
\text { side }\end{array}$ & Research Policy \\
\hline 49 & Edquist, $\mathrm{C}$ & 2012 & $\begin{array}{l}\text { Public Procurement for Innovation as mission-oriented } \\
\text { innovation policy }\end{array}$ & Research Policy \\
\hline 50 & Kesidou, Effie & 2012 & $\begin{array}{l}\text { On the drivers of eco-innovations: Empirical evidence from the } \\
\text { UK }\end{array}$ & RESEARCH POLICY \\
\hline 51 & Guerzoni, Marco & 2015 & $\begin{array}{l}\text { Demand-side vs. supply-side technology policies: Hidden } \\
\text { treatment and new empirical evidence on the policy mix }\end{array}$ & RESEARCH POLICY \\
\hline 52 & Rogge, Karoline S & 2016 & $\begin{array}{l}\text { Policy mixes for sustainability transitions: An extended concept } \\
\text { and framework for analysis }\end{array}$ & RESEARCH POLICY \\
\hline 53 & Raiteri, Emilio & 2018 & $\begin{array}{l}\text { A time to nourish? Evaluating the impact of public procurement } \\
\text { on technological generality through patent data }\end{array}$ & RESEARCH POLICY \\
\hline 54 & $\mathrm{Yi}, \mathrm{H}$ & 2012 & $\begin{array}{l}\text { Policy Tool Interactions and the Adoption of State Renewable } \\
\text { Portfolio Standards }\end{array}$ & Review of Policy Research \\
\hline 55 & Puig-Pey, Ana & 2017 & Public entities driven robotic innovation in urban areas & $\begin{array}{l}\text { ROBOTICS AND AUTONOMOUS } \\
\text { SYSTEMS }\end{array}$ \\
\hline 56 & Vonortas, N S & 2000 & $\begin{array}{l}\text { Technology policy in the United States and the European } \\
\text { Union: Shifting orientation towards technology users }\end{array}$ & Science and Public Policy \\
\hline 57 & Arocena, $\mathrm{R}$ & 2010 & $\begin{array}{l}\text { Weak knowledge demand in the South: Learning divides and } \\
\text { innovation policies }\end{array}$ & Science and Public Policy \\
\hline 58 & Timmermans, Bram & 2013 & $\begin{array}{l}\text { Coordinated unbundling: A way to stimulate entrepreneurship } \\
\text { through public procurement for innovation }\end{array}$ & SCIENCE AND PUBLIC POLICY \\
\hline 59 & Leitch, S & 2014 & $\begin{array}{l}\text { The fall of research and rise of innovation: Changes in New } \\
\text { Zealand science policy discourse }\end{array}$ & Science and Public Policy \\
\hline 60 & Bergek, A & 2015 & $\begin{array}{l}\text { Integrating the supply and demand sides of public support to } \\
\text { new technology-based firms }\end{array}$ & Science and Public Policy \\
\hline 61 & Georghiou, Luke & 2016 & $\begin{array}{l}\text { Signaling and accrediting new technology: Use of procurement } \\
\text { for innovation in China }\end{array}$ & SCIENCE AND PUBLIC POLICY \\
\hline 62 & Boon, Wouter & 2018 & $\begin{array}{l}\text { Demand, challenges, and innovation. Making sense of new } \\
\text { trends in innovation policy }\end{array}$ & SCIENCE AND PUBLIC POLICY \\
\hline 63 & Bugge, Markus M & 2018 & $\begin{array}{l}\text { Governing socio-technical change: Orchestrating demand for } \\
\text { assisted living in ageing societies }\end{array}$ & SCIENCE AND PUBLIC POLICY \\
\hline 64 & Chicot, Julien & 2018 & Public procurement of innovation: a review of rationales, & SCIENCE AND PUBLIC POLICY \\
\hline
\end{tabular}




\begin{tabular}{|c|c|c|c|c|}
\hline$\#$ & Authors & Year & Title & Journal / Conference \\
\hline & & & designs, and contributions to grand challenges & \\
\hline 65 & Wesseling, Joeri H & 2018 & $\begin{array}{l}\text { Public procurement for innovation to help meet societal } \\
\text { challenges: a review and case study }\end{array}$ & SCIENCE AND PUBLIC POLICY \\
\hline 66 & $\begin{array}{l}\text { Trindade, Paula } \\
\text { Cayolla }\end{array}$ & 2018 & $\begin{array}{l}\text { SPP Toolbox: Supporting Sustainable Public Procurement in the } \\
\text { Context of Socio-Technical Transitions }\end{array}$ & SUSTAINABILITY \\
\hline 67 & Jang, E K & 2015 & Policy instruments for eco-innovation in Asian countries & Sustainability (Switzerland) \\
\hline 68 & Mengolini, A & 2016 & $\begin{array}{l}\text { Exploring community-oriented approaches in demand side } \\
\text { management projects in Europe }\end{array}$ & Sustainability (Switzerland) \\
\hline 69 & Jiang, C & 2018 & $\begin{array}{l}\text { The effectiveness of government subsidies on manufacturing } \\
\text { innovation: Evidence from the new energy vehicle industry in } \\
\text { China }\end{array}$ & Sustainability (Switzerland) \\
\hline 70 & Safarzyńska, K & 2010 & $\begin{array}{l}\text { Demand-supply coevolution with multiple increasing returns: } \\
\text { Policy analysis for unlocking and system transitions }\end{array}$ & $\begin{array}{l}\text { Technological Forecasting and Social } \\
\text { Change }\end{array}$ \\
\hline 71 & Yun, $\mathrm{S}$ & 2015 & $\begin{array}{l}\text { Advancing societal readiness toward renewable energy system } \\
\text { adoption with a socio-technical perspective }\end{array}$ & $\begin{array}{l}\text { Technological Forecasting and Social } \\
\text { Change }\end{array}$ \\
\hline 72 & Caloghirou, Y & 2016 & $\begin{array}{l}\text { Public procurement for innovation: A novel eGovernment } \\
\text { services scheme in Greek local authorities }\end{array}$ & $\begin{array}{l}\text { Technological Forecasting and Social } \\
\text { Change }\end{array}$ \\
\hline 73 & Steward, F & 2012 & $\begin{array}{l}\text { Transformative innovation policy to meet the challenge of } \\
\text { climate change: Sociotechnical networks aligned with } \\
\text { consumption and end-use as new transition arenas for a low- } \\
\text { carbon society or green economy }\end{array}$ & $\begin{array}{l}\text { Technology Analysis and Strategic } \\
\text { Management }\end{array}$ \\
\hline 74 & Tsoutsos, T D & 2005 & $\begin{array}{l}\text { The sustainable diffusion of renewable energy technologies as } \\
\text { an example of an innovation-focused policy }\end{array}$ & Technovation \\
\hline 75 & Cohen, B & 2014 & $\begin{array}{l}\text { Municipal demand-side policy tools and the strategic } \\
\text { management of technology life cycles }\end{array}$ & Technovation \\
\hline 76 & Saastamoinen, $\mathbf{J}$ & 2018 & $\begin{array}{l}\text { Should SMEs pursue public procurement to improve innovative } \\
\text { performance? }\end{array}$ & Technovation \\
\hline 77 & Lember, $\mathrm{V}$ & 2011 & Urban competitiveness and public procurement for innovation & Urban Studies \\
\hline 78 & Srinivas, $\mathrm{S}$ & 2006 & $\begin{array}{l}\text { Industrial Development and Innovation: Some Lessons from } \\
\text { Vaccine Procurement }\end{array}$ & World Development \\
\hline
\end{tabular}

This is an Open Access article distributed under the terms of the Creative Commons Attribution-Non-Commercial-No Derivatives License (http://creativecommons.org/licenses/by-nc-nd/4.0/), which permits non-comercial re-use and distribution, provided the original work is properly cited, and is not altered or transformed in any way. 